Acta vet. scand. $1986,27,440-452$.

From the Department of Food Hygiene, Norwegian College of Veterinary Medicine, Oslo, the Norwegian Institute for Water Research,

Oslo and the Water Laboratory, National Swedish Environment

Protection Board, Uppsala.

\title{
OBSERVATIONS OF TOXIC BLUE-GREEN ALGAE (CYANOBACTERIA) IN SOME SCANDINAVIAN LAKES
}

\author{
By \\ Kjetil Berg, Olav M. Skulberg, Randi Skulberg, Bjarne Underdal \\ and Torbjørn Willén
}

\begin{abstract}
BERG, KJETIL, OLAV M. SKULBERG, RANDI SKULBERG, BJARNE UNDERDAL and TORBJ $\emptyset R N$ WILLEN: Observations of toxic blue green algae (Cyanobacteria) in some Scandinavian lakes. Acta vet. scand. $1986,27,440-452$. - Blooms of blue-green algae from 51 eutrophic Scandinavian lakes were investigated during the period $1978-1984$, to ascertain the occurrence of toxinogenic species.

Toxicity assays were performed by intraperitoneal injection of suspensions of freeze-dried algal material in mice. Toxin-producing blue-green algae were found in 30 lakes. They belonged to 11 different species of the six genera Anabaena, Aphanizomenon, Gomphosphaeria, Microcystis, Nodularia and Oscillatoria.

The presence of toxinogenic strains of blue-green algae seemed quite constant in several of the localities studied. In some lakes, more than one toxic species were found to develop simultaneously. The level of toxicity showed large variation $\left(\mathrm{MLD}_{100}, 6\right.$ to $\left.>2500 \mathrm{mg} / \mathrm{kg}\right)$, but clinical and pathological changes were quite uniform.

The results indicate that water-blooms of toxin-producing bluegreen algae, in the geographical area in question, are regionally widespread. In some localities, blooms of blue-green algae are apparently always toxic. Several aspects of the toxic blue-green algae problem are discussed.
\end{abstract}

toxicity assays; Anabaena; Aphanizomenon; Gomphosphaeria; Microcystis; Nodularia;

os cillatoria.

The pollution of inland waters in the Scandinavian peninsula (Norway and Sweden) has in many places resulted in prolific development of aquatic vegetation, e.g. blooms of blue-green algae (Cyanobacteria, CYANOPHYCEAE) in eutrophic lakes (Skulberg 
1971, Willén 1971, Brettum 1979). Among the undesirable effects are those leading to deterioration of water resources and interference with public health. The mass growth of blue-green algae may upset the normal food chains in lakes, the water may become unacceptable as drinking water due to unsatisfactory taste and odour, and toxic effects may be experienced.

Toxic species of blue-green algae have been reported from several geographical regions and illness or death in mammals, birds and fish have been caused by the toxins produced (reviewed by Carmichael 1981).

Due to the lack of data from the Scandinavian area, investigations were started to clarify the prevailing circumstances. The objectives of this study were to ascertain the occurrence of toxic blue-green algae, to determine the species involved and to test the bloom-forming species for toxicity.

\section{MATERIALS AND METHODS}

Area

The areas investigated were in the more densely populated part of Norway and Sweden. In addition, a few Finnish localities were included (Fig. 1). The localities studied, 51 in number, were selected on the basis of reports of repeatedly heavy growths of blue-green algae. Some of these waters are used for recreational purposes and as sources of drinking water.

\section{Samples}

Phytoplankton observations were carried out at irregular intervals during the period of investigation (1978-1984). Samples collected included (a) tow net samples (mesh size $25 \mu \mathrm{m}$ ), (b) samples for quantitative analysis and (c) seston samples on membrane filters (pore size $0.45 \mu \mathrm{m}$ ). Samples were mainly collected during summer and autumn when the populations of blue-green algae were well developed. The main regional species of blue-green algae were isolated and cultured. These clone cultures of strains are kept in the NIVA culture collection of algae.

Identification of organisms and preparation of samples for toxicity testing

The identification of organisms was performed using an optical microscope on living and formalin preserved material 


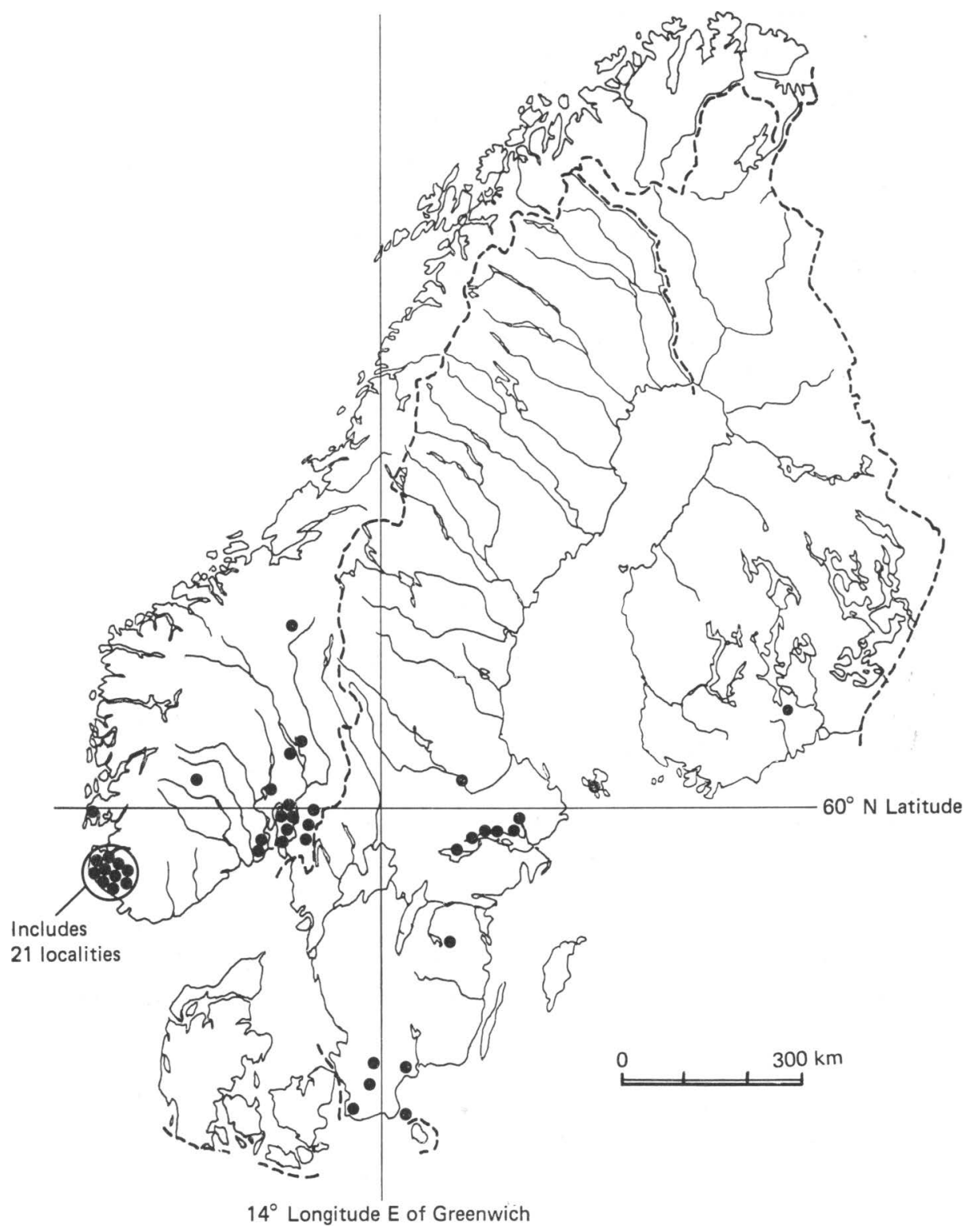

Figure 1. Geographical area and localities investigated.

(Geitler 1932). Samples were concentrated in the laboratory by passage through plankton nets (mesh sizes 10,25 or $50 \mu \mathrm{m}$ ) and freeze-dried. From freeze-dried material, suspensions were made in sterile $0.9 \% \mathrm{NaCl}$, equivalent to $50 \mathrm{mg}$ dry weight per $\mathrm{ml}$. 


\section{Toxicity tests}

The acute toxicity of the extracts was determined using a standard mouse bioassay injecting 2 animals intraperitoneally at each dose level (Skulberg 1979). Mice used were Bom: NMRI, females, $20-25 \mathrm{~g}$. Toxicity was expressed in terms of mouse units per $\mathrm{g}$ of freeze-dried material $(\mathrm{MU} / \mathrm{g})$. A mouse unit was defined as the minimum dose necessary to kill a $20 \mathrm{~g}$ mouse within $4 \mathrm{~h}$. Symptoms developing after intraperitoneal injection were observed. Pathological examinations were performed on mice that died during the experiments. Surviving animals were kept under observation for 4 days.

\section{RESULTS}

Toxic populations and species of blue-green algae involved

Of the 51 localities investigated, toxin-producing strains of blue-green algae were found in 30 cases. Toxic Anabaena flos-aquae, Microcystis aeruginosa and Oscillatoria agardhii dominated this material. The results of the survey are summarized in Table 1.

Eleven different species proved to have toxin-producing strains. These included strains of Anabaena, Microcystis, Aphanizomenon, Gomphosphaeria, Nodularia and Oscillatoria. In some lakes (e.g. Lake Frøylandsvatnet, Lake Mälaren) 2 or more species of toxic blue-green algae were present simultaneously or during different periods.

A large number of water-bloom episodes were recorded in the Jaeren region, on the south-western coast of Norway. This area is a very intensive agricultural district. 1982-findings in the region are presented in Fig. 2.

\section{Symptoms and effects of intoxication}

The toxicity of the toxic algae showed large variations from one sample to another, ranging from $<20$ to around $8000 \mathrm{MU}$ per g of freeze-dried material. However, clinical and pathological findings were much the same, regardless of the origin or concentration of the injections given, as long as they were $>1 \mathrm{MU}$. Following the intraperitoneal administration of a lethal dose, there was a latent period of 10 to $30 \mathrm{~min}$. The initial main symptoms were incoordination and paralysis of the hind quarters, lethargy, piloerection and pallor. The lethargy altered with short 
Tab le 1. Assays for toxicity of freeze-dried material from natural populations of blue-green algae.

\begin{tabular}{|c|c|c|c|c|}
\hline Locality & & $\begin{array}{l}\text { Date of } \\
\text { collection }\end{array}$ & Organism & $\begin{array}{l}\text { Content of } \\
\text { toxin, MU/g }\end{array}$ \\
\hline $\begin{array}{l}\text { Bakkavatn, } \\
\text { Rogaland }\end{array}$ & - & 1984 & Anabaena flos-aquae & 100 \\
\hline $\begin{array}{l}\text { Bråsteinvatn, } \\
\text { Rogaland }\end{array}$ & - & 13.9 .1983 & Anabaena flos-aquae & 75 \\
\hline $\begin{array}{l}\text { Edlandsvatn, } \\
\text { Rogaland }\end{array}$ & - & 13.8.1981 & Anabaena flos-aquae & 75 \\
\hline $\begin{array}{l}\text { Haugatjønn } \\
\text { Sør-Trøndelag }\end{array}$ & - & 9.8 .1984 & Anabaena flos-aquae & 500 \\
\hline $\begin{array}{l}\text { Hjälmaren, } \\
\text { Södermanland }\end{array}$ & - & 6.9.1982 & Anabaena flos-aquae & 300 \\
\hline $\begin{array}{l}\text { Klugevatn, } \\
\text { Rogaland }\end{array}$ & - & 2.8 .1984 & Anabaena flos-aquae & 0 \\
\hline $\begin{array}{l}\text { Limavatn, } \\
\text { Rogaland }\end{array}$ & - & 4.8 .1981 & Anabaena flos-aquae & 80 \\
\hline $\begin{array}{l}\text { Ragsvatn, } \\
\text { Rogaland }\end{array}$ & - & 2.10 .1984 & Anabaena flos-aquae & 0 \\
\hline $\begin{array}{l}\text { Rødungen, } \\
\text { Buskerud }\end{array}$ & 一 & 22.8 .1984 & Anabaena flos-aquae & $\mathbf{0}$ \\
\hline $\begin{array}{l}\text { Seldalsvatn, } \\
\text { Rogaland }\end{array}$ & - & 13.9 .1983 & Anabaena flos-aquae & 0 \\
\hline $\begin{array}{l}\text { Storamos, } \\
\text { Rogaland }\end{array}$ & - & 9.8 .1984 & Anabaena flos-aquae & 200 \\
\hline $\begin{array}{l}\text { Vostervatn, } \\
\text { Rogaland }\end{array}$ & 一 & 6.8.1984 & Anabaena flos-aquae & $\mathbf{0}$ \\
\hline $\begin{array}{l}\text { Øyeren, } \\
\text { Akershus }\end{array}$ & - & 29.7.1984 & Anabaena flos-aquae & 0 \\
\hline $\begin{array}{l}\text { Landavatn, } \\
\text { Rogaland }\end{array}$ & - & 12.8 .1984 & Anabaena solitaria & 0 \\
\hline $\begin{array}{l}\text { Stokkalandsvatn, } \\
\text { Rogaland }\end{array}$ & - & 16.8.1982 & Anabaena spiroides & 40 \\
\hline $\begin{array}{l}\text { Breiavatn, } \\
\text { Rogaland }\end{array}$ & -1 & 10.11.1983 & $\begin{array}{l}\text { Anabaena spiroides }+ \\
\text { Gomphosphaeria naegeliana }\end{array}$ & 0 \\
\hline $\begin{array}{l}\text { Bakkavatn, } \\
\text { Rogaland }\end{array}$ & 一 & 1979 & Anabaena sp. & 0 \\
\hline $\begin{array}{l}\text { Langen, } \\
\text { Akershus }\end{array}$ & - & 4.10 .1984 & Anabaena sp. & 0 \\
\hline $\begin{array}{l}\text { Bjørkelangen, } \\
\text { Akershus }\end{array}$ & - & 30.8 .1984 & Aphanizomenon flos-aquae & $<20$ \\
\hline $\begin{array}{l}\text { Galten-Mälaren, } \\
\text { Uppland }\end{array}$ & - & 11.8.1982 & Aphanizomenon flos-aquae & 0 \\
\hline $\begin{array}{l}\text { Holtavann, } \\
\text { Rogaland }\end{array}$ & - & 9.8 .1984 & Aphanizomenon flos-aquae & 0 \\
\hline $\begin{array}{l}\text { Pildammen, } \\
\text { Malm } \varnothing \text {, Skåne }\end{array}$ & - & 17.7.1983 & Aphanizomenon flos-aquae & 0 \\
\hline $\begin{array}{l}\text { Västeråsfjärden, } \\
\text { Mälaren, Västmanland }\end{array}$ & - & 17.8.1982 & Aphanizomenon flos-aquae & 0 \\
\hline
\end{tabular}


Table 1 (continued).

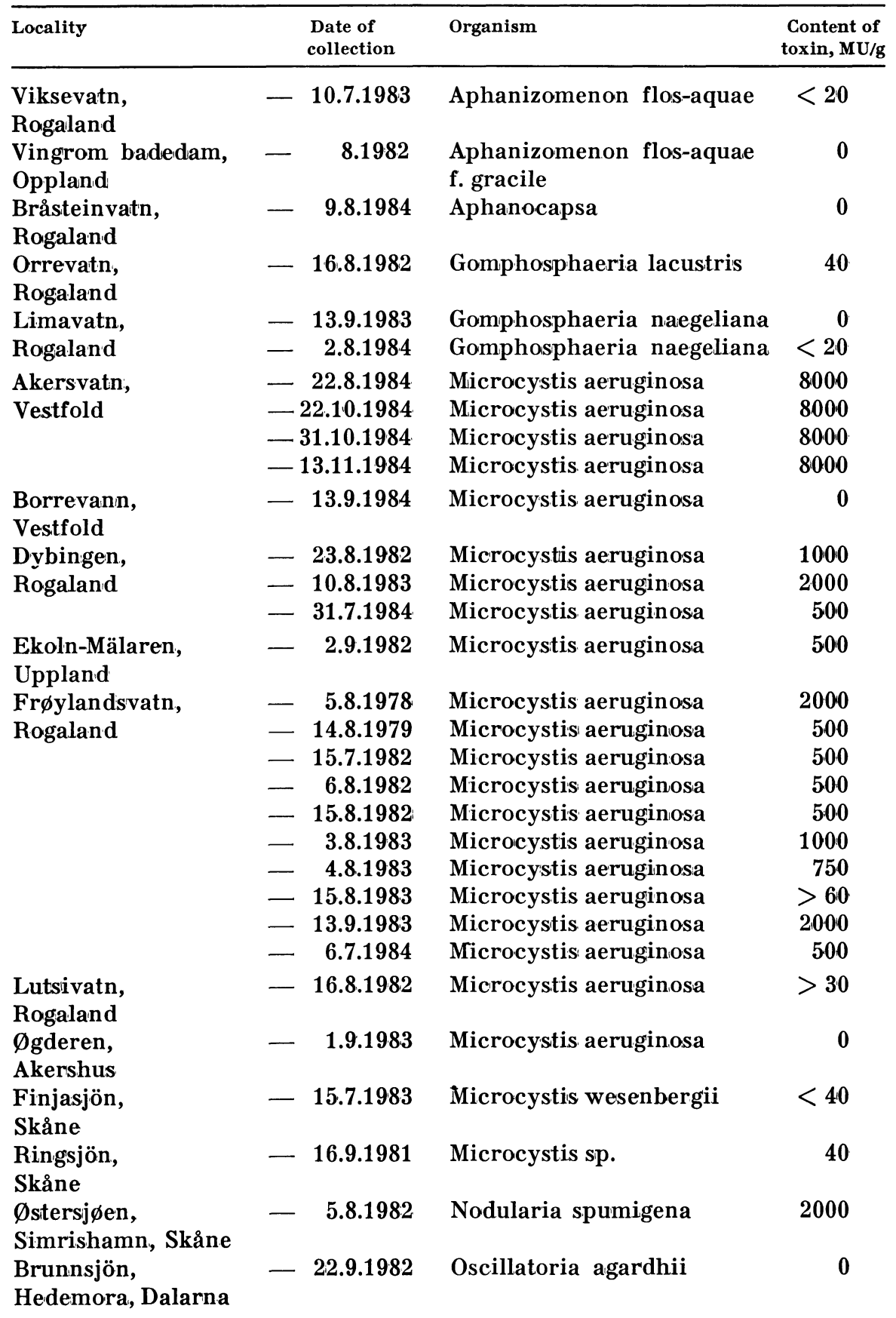


Table 1 (continued).

\begin{tabular}{|c|c|c|c|c|}
\hline Locality & & $\begin{array}{l}\text { Date of } \\
\text { collection }\end{array}$ & Organism & $\begin{array}{l}\text { Content of } \\
\text { toxin, MU/g }\end{array}$ \\
\hline $\begin{array}{l}\text { Helgetjeřn } \\
\text { Østfold }\end{array}$ & - & 18.8.1978 & Oscillatoria agardhii & 0 \\
\hline $\begin{array}{l}\text { Holstadvatn, } \\
\text { Akershus }\end{array}$ & 一 & 20.9 .1983 & Oscillatoria agardhii & 80 \\
\hline $\begin{array}{l}\text { Markusbölefjärden, } \\
\text { Åland }\end{array}$ & - & 19.8 .1984 & Oscillatoria agardhii & 100 \\
\hline $\begin{array}{l}\text { Årungen, } \\
\text { Akershus }\end{array}$ & $\begin{array}{l}- \\
-\end{array}$ & $\begin{array}{l}27.7 .1979 \\
23.9 .1980 \\
17.9 .1981 \\
20.9 .1983\end{array}$ & $\begin{array}{l}\text { Oscillatoria agardhii } \\
\text { Oscillatoria agardhii } \\
\text { Oscillatoria agardhii } \\
\text { Oscillatoria agardhii }\end{array}$ & $\begin{array}{l}0 \\
0 \\
0 \\
0\end{array}$ \\
\hline $\begin{array}{l}\text { Gjersjøen, } \\
\text { Akershus }\end{array}$ & - & $\begin{array}{l}19.4 .1980 \\
23.9 .1980 \\
21.8 .1981\end{array}$ & $\begin{array}{l}\text { Oscillatoria agardhii var. } \\
\text { Oscillatoria agardhii var. } \\
\text { Oscillatoria agardhii var. }\end{array}$ & $\begin{array}{l}500 \\
500 \\
500\end{array}$ \\
\hline $\begin{array}{l}\text { Kolbotnvatn, } \\
\text { Akershus }\end{array}$ & - & 25.4 .1978 & Oscillatoria agardhii var. & 500 \\
\hline $\begin{array}{l}\text { Levrasjön, } \\
\text { Skåne }\end{array}$ & - & 25.8.1981 & Oscillatoria agardhii var. & $\mathbf{0}$ \\
\hline $\begin{array}{l}\text { Lilla Ullfjärden, } \\
\text { Mälaren, Uppland }\end{array}$ & - & 22.4.1982 & Oscillatoria agardhii var. & 300 \\
\hline $\begin{array}{l}\text { Stora Ullfjärden, } \\
\text { Mälaren, Uppland }\end{array}$ & - & 28.9.1982 & Oscillatoria agardhii var. & 1000 \\
\hline $\begin{array}{l}\text { Långsjön, } \\
\text { Mariehamn, Åland }\end{array}$ & - & 11.4 .1984 & Oscillatoria agardhii var. & 500 \\
\hline $\begin{array}{l}\text { Øren, } \\
\text { Østergötland }\end{array}$ & - & $\begin{array}{r}25.8 .1981 \\
4.1982\end{array}$ & $\begin{array}{l}\text { Oscillatoria agardhii var. } \\
\text { Oscillatoria agardhii var. }\end{array}$ & $\begin{array}{r}75 \\
500\end{array}$ \\
\hline Vesijärvi, Lahti & - & 1.4 .1984 & Oscillatoria. agardhii var. & 150 \\
\hline $\begin{array}{l}\text { Bjørkelangen, } \\
\text { Akershus }\end{array}$ & - & 1.9 .1983 & $\begin{array}{l}\text { Oscillatoria agardhii } \\
\text { var. isothrix }\end{array}$ & 750 \\
\hline \multirow[t]{3}{*}{$\begin{array}{l}\text { Fr } \varnothing \text { ylandsvatn, } \\
\text { Rogaland }\end{array}$} & 一 & 5.7 .1983 & $\begin{array}{l}\text { Oscillatoria agardhii } \\
\text { var. isothrix }\end{array}$ & 1000 \\
\hline & - & 30.7 .1984 & $\begin{array}{l}\text { Oscillatoria agardhii } \\
\text { var. isothrix }\end{array}$ & 500 \\
\hline & 一 & 27.8.1984 & $\begin{array}{l}\text { Oscillatoria agardhii } \\
\text { var. isothrix }\end{array}$ & 500 \\
\hline Vansjø, Østfold & - & & $\begin{array}{l}\text { Oscillatoria agardhii } \\
\text { var. isothrix }\end{array}$ & 300 \\
\hline $\begin{array}{l}\text { Mjøsa, } \\
\text { Hedmark og }\end{array}$ & 一 & 1976 & $\begin{array}{l}\text { Oscillatoria bornetii } \\
\text { f. tenuis }\end{array}$ & 0 \\
\hline Oppland & - & 1978 & $\begin{array}{l}\text { Oscillatoria bornetii } \\
\text { f. tenuis }\end{array}$ & 0 \\
\hline $\begin{array}{l}\text { Steinsfjorden, } \\
\text { Buskerud }\end{array}$ & 一 & 1978 & Oscillatoria rubescens var. & 1000 \\
\hline $\begin{array}{l}\text { Bjørkelangen, } \\
\text { Akershus }\end{array}$ & - & 11.7.1984 & Div. & 50 \\
\hline $\begin{array}{l}\text { Stokkalandsvatn, } \\
\text { Rogaland }\end{array}$ & 一 & 5.7 .1984 & Div. & 100 \\
\hline
\end{tabular}




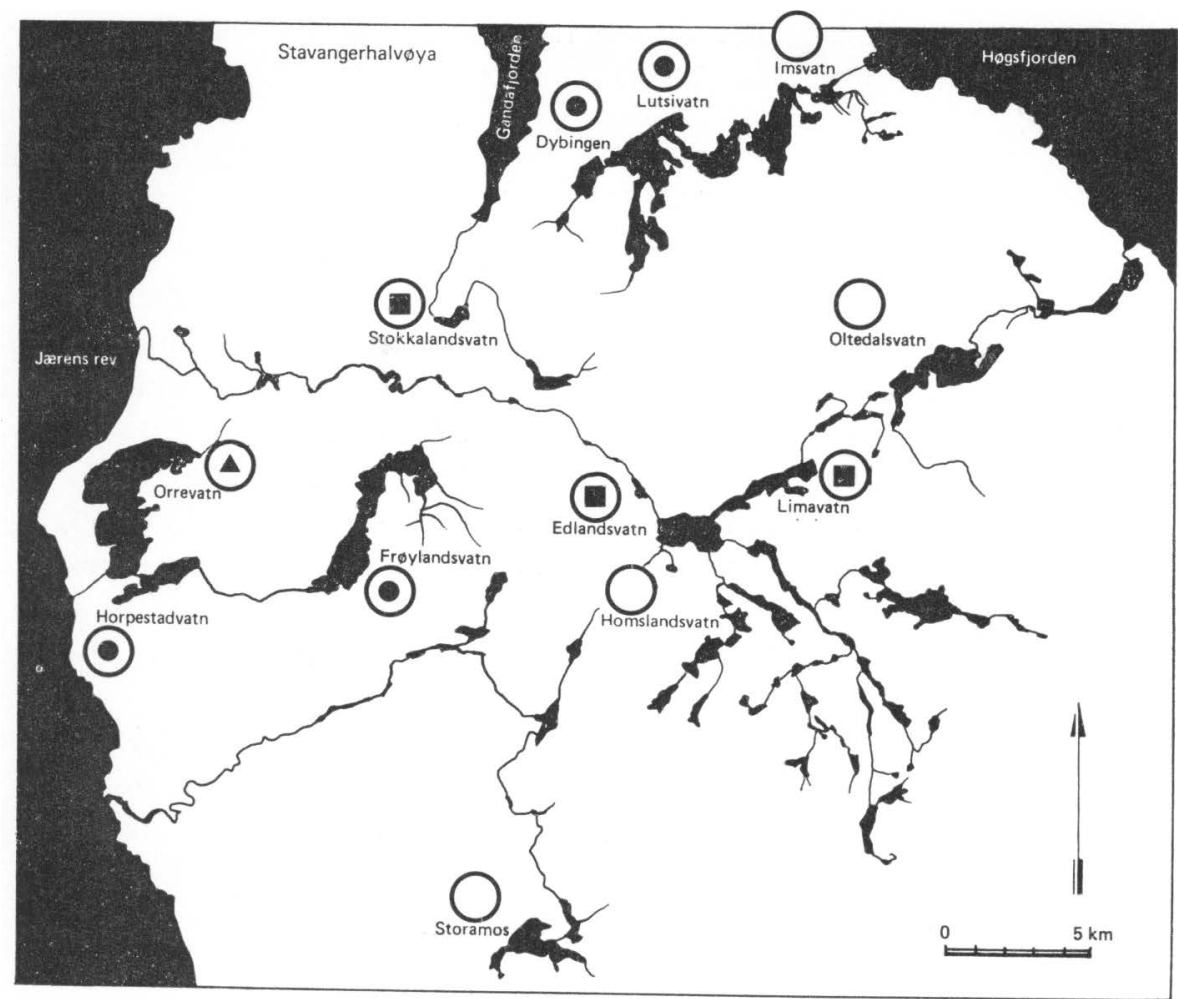

Figure 2. Example of occurrence of toxin-producing blue-green algae. Observations from Jaeren, 1982.

Toxin-producing blue-green algae not found.

(2) Toxin-producing Microcystis.

(-) Toxin-producing Anabaena.

(A) Toxin-producing Gomphosphaeria.

periods of tremor and mild convulsions. Subsequently the animals became weaker, and respiration became labored and infrequent. Death occurred 35-200 min after administration.

Post-mortem examination revealed a pale carcass and an enlarged dark red liver, the surface of which was mottled. Other organs were pale. Histological changes were most pronounced in the liver. The organ was engorged with blood, and there were widespread haemorrhages. The liver parenchyma showed dege- 
neration and dissociation of the liver cords. Some hepatocytes were necrotic, and the blood vessels contained eosinophilic masses.

\section{DISCUSSION}

Our data strongly indicate that blooms of toxic blue-green algae are a regular phenomenon in eutrophic inland waters in the region in question. Intoxications of fish, birds and mammals occur periodically and several episodes have been reported during the last decade (Nygård 1977, Skulberg 1979, Haaland et al. 1983, Lind et al. 1983, Persson et al. 1984, Lindholm \& Eriksson 1985).

A few results from determinations of the toxin content in blue-green algae from water-blooms in Norway have been published earlier (Skulberg 1979, Østensvik et al. 1981). It is now possible to present results obtained from extensive observations made in a wide geographical area.

The main toxic species of blue-green algae reported in the literature so far have been Microcystis aeruginosa, Aphanizomenon flos-aquae and Anabaena flos-aquae (Carmichael 1981). The present investigations demonstrate that several other species include toxin-producing strains. Thus Microcystis wesenbergii, Gomphosphaeria lacustris, Anabaena spiroides and the 4 species of the Oscillatoria agardhii-rubescens group (Skulberg \& Skulberg 1985) were identified and documented to have toxic properties. This indicates that toxinogenic strains are present to a greater extent among species of blue-green algae than previously assumed.

Examplified by the Jaeren findings, mild climate and nutrient-rich conditions favour growth of blue-green algae. Toxin-producing blooms represent a threat to grazing livestock and wildife in such districts.

The acute toxicity tests on natural populations (waterblooms) of blue-green algae reported here revealed corresponding clinical and pathological findings to those described for the hepatotoxins produced by Microcystis aeruginosa (Carmichael $\&$ Mahmood 1984). Death seems to be caused by the development of a fatal shock due to internal liver haemorrhage and decrease in circulating ${ }^{*}$ blood volume.

The results show that the water-blooms investigated varied with respect to the toxin content. The highest levels determined were, as stated earlier, about $8000 \mathrm{MU}$ per g, and the lowest $<20$ 
MU per g. These bioassay results are in accordance with those found in other investigations on toxic water-blooms and cultured isolates of toxic blue-green algae around the world (Carmichael 1981, Leeuwangh et al. 1983, Jackson et al. 1984, Codd \& Bell 1985 ). Expressed as $M L D_{100}$, toxicity was in the range $6 \mathrm{mg} / \mathrm{kg}$ to $>2500 \mathrm{mg} / \mathrm{kg}$, and the waterblooms concerned should be characterized as slightly to highly toxic.

One of the common problems when studying blooms of toxic blue-green algae is the variability and rapid fluctuation in both the blooms and their toxicity. The usual situation reported (Carmichael 1981) for bloom-forming blue-green algae is one in which non-toxic blooms dominate, with toxic blooms occurring only occasionally under certain undefined environmental conditions. The results obtained during this investigation are somewhat in contrast to this general picture. Blooms of blue-green algae in some of the water systems studied are apparently always toxic. An example is Lake Frøylandsvatnet, Rogaland. All samples tested from this lake in the period 1978-1984 were found to be toxic.

Populations of toxic and non-toxic strains of the same species may be present simultaneously in the same lake(Carmichael \& Gorham 1981). This was not confirmed by our study. Parallel samples from toxic blooms always proved to be toxic.

The factors producing a toxic water-bloom of blue-green algae are not yet understood. For example, Lake Gjersjøen and Lake Årungen in Akershus, Norway are situated in close proximity only 5 kilometers apart. Both lakes are highly eutrophic and water-blooms of blue-green algae regularly develop. In both lakes the dominating species belong to the Oscillatoria agardhiigroup (Skulberg \& Skulberg 1985). All toxicity tests carried out during 1978-1984 with samples from Lake Gjersjøen have shown the presence of toxic populations, whereas no instances of toxic water-blooms have been demonstrated in the nearby Lake Arrungen. One of the questions which then arises is whether the vegetation of blue-green algae undergoes a separate speciation to the individual lake or water system concerned.

Nodularia spumigena is worthy of special mention. Although this blue-green alga was the first to be reported as being implicated in poisonings of domestic animals (Francis 1878), reports in the literature confirming the toxicity of blooms of Nodularia spumigena are very sparse. Episodes of fatal intoxication 
of dogs in Sweden in July 1982 provided an opportunity to investigate and verify that populations of Nodularia spumigena in the Baltic Sea can produce toxic strains (Lind et al. 1983).

Two cases involving toxic blooms of blue-green algae in Finnish inland waters need special consideration. During November 1982, a massive kill of roach (Rutilus rutilus L.) occurred in Lake Vesijärvi, Lahti. A red strain of Oscillatoria agardhii var. had invaded the lake prior to this event. The cause of mortality was never fully elucidated, though algal intoxication was suspected (Persson et al. 1984). Samples of the red water-bloom were collected during the winter 1984, and the intraperitoneal mouse bioassay revealed the presence of blue-green algal toxin in the material of Oscillatoria. Lake Vesijärvi was the first locality in the Nordic countries associated with reports of animal losses due to blue-green algae (Hindersson 1933).

During recent years Oscillatoria agardhii var. has also invaded 2 lakes on the Åland Islands in the Baltic Sea. Lake Langsjön and Lake Markusbölefjärden constitute part of the municipal water supply to the city of Mariehamn. Toxicity tests carried out on samples of Oscillatoria clearly demonstrated the presence of blue-green algal hepatotoxins, both in the red form dominating in April, and in the green form dominating later in the summer. In the summer of 1984 (May-September), continuous fish kills and suspicious deaths of aquatic birds were noted (Lindholm \& Eriksson 1985). Circumstances indicate that the blue-green algae might have caused the animal fatalities reported.

Many aspects of blue-green algal toxicity are still not understood. Both acute and chronic phenomena are involved when these toxic compounds interact with living organisms. In order to tackle the problems posed, including assessment of toxic hazards to aquatic and terrestric life, further studies are required.

\section{ACKNOWLEDGEMENTS}

The authors thank Wayne W. Carmichael and Geoffrey A. Codd for helpful discussions, advice and encouragement during the preparation of this paper.

\section{REFERENCES}

Brettum, P.: Planteplankton som indikator på trofinivå i norske innsjøer. (Phytoplankton as indicator of trophical level in Norwegian lakes). Rapport XB-07, NIVA, Oslo 1979, 102 pp. 
Carmichael, W. W.: Freshwater Blue-Green Algae (Cyanobacteria) Toxins - A Review. In: The Water Environment: Algal Toxins and Health. Ed. W. W. Carmichael. Plenum Press, New York 1981, pp. $1-13$.

Carmichael, W. W. \& P. R. Gorham: The Mosaic Nature of Toxic Blooms of Cyanobacteria. In: The Water Environment: Algal Toxins and Health. Ed. W. W. Carmichael. Plenum Press, New York 1981, pp. 161-172.

Carmichael, W. W. \& N. Mahmood: Toxins from Freshwater Cyanobacteria (Blue-Green Algae). In: Seafood Toxins. Ed. E. Ragelis, Amer. Chem. Soc. Symp. Ser. 262, 1984, pp. 377-389.

Codd, G. A. \& S. G. Bell: Eutrophication and toxic cyanobacteria in freshwaters. J. Inst. Wat. Pollut. Control 1985, in press.

Geitler., L.: Cyanophyceae. In: Kryptogamenflora. Ed. L. Rabenhorst.

Francis, G.: Poisonous Australian Lake. Nature 1878, 18, 11. Akad. Verlagsges., Leipzig 1932, 1196 pp.

Hindersson, R.: Förgiftning av nötkreatur genom sötvattensplankton. (Freshwater plankton poisoning of cattle). Finsk Vet.-T. 1933, 39, $179-189$.

Haaland, M., I. M. Solberg \& J. Øverås: Forgiftning av sau og storfe med blågrønnalger. (Blue-green algal poisoning of sheep and cattle). Norsk Vet.-T. $1983,95,171-173$.

Jackson, R. B., A. McInnes, I. R. Falconer \& M. T. C. Runnegar: Clinical and pathological changes in sheep experimentally poisoned by the blue-green alga Microcystis aeruginosa. Vet. Pathol. 1984, $21,102-113$.

Leeuwangh, P., F. I. Kappers, M. Dekker \& W. Koerselman: Toxicity of cyanobacteria in Dutch lakes and reservoirs. Aquat. Toxicol. $1983,4,63-72$.

Lind, M. G., L. Edler, S. Fern $\varnothing$, R. Lundberg \& P. O. Nilsson: Risken för algförgiftning har ökat - hundar avled efter bad i södra östersjön. (Increased risk of algal poisoning — dogs died after swimming in the southern Baltic Sea). Läkartidningen 1983, 80, $2734-2737$.

Lindholm, T. \& J. Eriksson: Problemalger och fiskdöd i ålandska vattentäkter. (Noxious algae and death of fish in lakes on Åland). Ympäristö ja terveys, 1985, 1/85, 41-44.

Nygård, J. J.: Toksiske blågrønnalger i ferskvann. (Toxic blue-green algae in freshwater). In: Norsk institutt for vannforskning 1976, NIVA, Oslo 1977, pp. 17-24.

Persson, P.-E., K. Sivonen, J. Keto, K. Kononen, M. Niemi \& H. Viljamaa: Potentially toxic blue-green algae (cyanobacteria) in Finnish natural waters. Aqua Fenn. 1984, 14, 2, 147-154.

Skulberg, O. M.: Eutrofiering og biologiske forandringer i noen $\varnothing$ stnorske vannforekomster. (Eutrophication and biological changes in some waters from eastern Norway). In: Forurensning og biologisk miljøvern. Ed. I. Mysterud, Universitetsforlaget, Oslo 1971, pp. $219-235$. 
Skulberg, O. M. (ed.) : Giftvirkninger av blågrønnalger — f $\emptyset$ rste tilfelle av Microcystis-forgiftning registrert i Norge. (Toxic effects of blue-green algae - first case of Microcystis-poisoning reported from Norway). Temarapport 4, NIVA, Oslo 1979, $42 \mathrm{pp}$.

Skulberg, O. M. \& R. Skulberg: Planktic species of Oscillatoria (Cyanophyceae) from Norway. Characterization and classification. Arch. Hydrobiol. 1985, Suppl. 71, 1/2, 157-174.

Willén, T.: Föroreningar i sötvatten. (Pollution in freshwater). In: Forurensning og biologisk miljøvern. Ed. I. Mysterud, Universitetsforlaget, Oslo 1971, pp. 205-218.

$\emptyset$ stensvik, Ø., O. M. Skulberg \& N. E. Søli: Toxicity Studies with BlueGreen Algae from Norwegian Inland Waters. In: The Water Environment: Algal Toxins and Health, Ed. W. W. Carmichael, Plenum Press, New York 1981, pp. 315-324.

\section{SAMMENDRAG}

Funn av giftige blågrønnalger $i$ endel skandinaviske innsjøer.

Oppblomstringer av blågrønnalger fra 51 eutrofe skandinaviske innsjøer ble unders $\varnothing \mathrm{kt}$ i perioden 1978-1984, for å fastslå utbredelsen av giftige arter.

Toksisitetstester ble utført ved intraperitoneal injeksjon av frysetørket algemateriale på mus. Toksinproduserende blågrønnalger ble funnet i 30 innsjøer. Algene tilhørte 11 forskjellige arter innen de 6 generaene Anabaena, Aphanizomenon, Gomphosphaeria, Microcystis, Nodularia og Oscillatoria.

Giftige blågrønnalgestammer syntes å være relativt permanent tilstede $\mathrm{i}$ flere av de unders $\varnothing \mathrm{kte}$ lokalitetene. I noen innsjøer ble det funnet mer enn en giftig stamme samtidig. Toksisitetsnivået varierte svært $\left(\mathrm{MLD}_{100} 6->2500 \mathrm{mg} / \mathrm{kg}\right)$, men de kliniske og patologiske endringene var nokså ensartede.

Resultatene indikerer at vannblomst med toksinproduserende blågrønnalger er relativt vanlig forekommende $\mathrm{i}$ deler av det unders $\varnothing \mathrm{kte}$ området. I noen lokaliteter er slike oppblomstringer tilsynelatende alltid giftige. Ulike sider av problematikken omkring giftige blågrønnalger diskuteres.

(Received June 23, 1986).

Reprints may be requested from: Kjetil Berg, the Department of Food Hygiene, Norwegian College of Veterinary Medicine, P. O. Box 8146 Dep., N-0033 Oslo 1, Norway. 